\title{
Investment efficiency of securities market: assessment methodology
}

\author{
Alexander Miller, Andrey Miller \\ Department of Economics and Financial policy, \\ Omsk State University n.a. F.M. Dostoevskiy, \\ Omsk, Russia \\ aem55@yandex.ru
}

\begin{abstract}
In the article, the actual problem of attracting investment into the regional economy is discussed. The subject of this research is the securities market as a mechanism for the redistribution of financial resources. The purpose of the research is the development of the interaction scheme which is efficient, effective and feasible in the current environment between the securities market and the regional economy. The theoretical basis of this research is the theory of the securities market. To achieve this goal, the authors used a functional-relational approach to the study of the activities of the securities market participants. During the research, the following results were obtained: possible submodels of interaction between the securities market participants were identified; the reserve of increasing the efficiency of the securities market in the regions of Western Siberia was revealed; the model of the priority interaction between the securities market participants for the benefit of the regional economy was built; the assessment of the possible effect of the development of the regional securities market on key indicators of the regional economy development was done. The obtained results are recommended for use in the development of regional economic policies and programmes of socio-economic development of regions. Long-term stimulation of the economic growth is a very complex process, but with the proper elaboration of the organizational issues, implementation of the proposed model of interaction among the securities market participants will ensure high investment and business activities of the regional economic entities.
\end{abstract}

Key words - regional economy, securities market, investments.

\section{INTRODUCTION}

In the context of modern complex economic environment, the relevance of the issue of investment activity stimulation in the regions of the Russian Federation is increasing. Currently, the regions face a shortage of investment resources and the low level of effectiveness of the mechanisms of accumulation and redistribution of these resources within a particular territory (region).

In the world practice, the securities market is recognized as one of the most effective mechanisms for the redistribution of financial resources required for economic development. A particular feature of the securities market is a multi-level nature of its functioning; that is, within the national securities market, a conditional allocation of territorial (regional) markets is possible. Under the regional securities market, the authors understand a conventionally allocated local securities market, the functioning of which is expressed in the activities of the regional securities market entities [1].

The problem of the current state of the securities market is that the securities market and the regional economy represent competing spheres of capital investment; and the flow of investment resources equalizing the rate of profit occurs between these spheres. The reason for this situation is the focus on the speculative activity on the securities market and the actual lack of demand for the securities market instruments on the part of economic entities [2]. The regional economy represents a field for the use and circulation of real capital (invested in fixed assets and advanced in working capital).

The securities market is now represented mainly by the relations over the circulation of the securities on the secondary market. That is, on the regional securities market, financial assets associated with the redistribution of property and nonproperty rights on securities (not with the growth of real capital of economic entities of the region) are traded. As a result, the financial resources accumulated by the regional securities market are not directed at the development of the regional economy [3]. They flow to the national level for speculative operations on the organized securities market [4]. Such model of the interaction actually suppresses a redistributive function of the securities market in favor of the commercial and speculative function.

\section{MATERIALS AND METHODS}

The theoretical basis of this research is the theory of finance. It enables one to justify the functional relations between the spheres of public and private finance, the impact of financial markets on the economy development, as well as the functions and tasks of the securities market.

The problem outlined above is considered as one of the most acute in the national economics: the securities market is not an effective mechanism for the redistribution of investment under current conditions in Russia [5]. At the same time, great potential of the securities market in terms of opportunities to stimulate economic growth is underlined both in foreign and domestic spheres ([6], [7]). In fact, the securities market acts as an alternative to a regional nonfinancial sector of the market, which diverts a significant part of financial resources [8]. The lack of funding within the 
economy of the entire region leads to a slowdown in structural adjustment of the regional economy [9]. Accordingly, the most important goal of the development and improvement of the regional securities market is the development of highquality cooperation between the regional economy and regional securities market [10].

The methodical basis of this research is a functional and relational approach, which allows us to study the nature and completeness of how the securities market performs its functions through the prism of the features of activity carried out by the market participants. The achievement of any outcome (for example, a certain level of ability to reallocate financial resources) is a consequence of the interaction of the securities market participants among themselves.

Thus, the securities market is a field of activity of entities of financial relations. Each of the entities operates on this market, interacting with other participants. Issuers attract resources in the process of issuance and placement of securities. Investors who have temporarily available funds provide issuers with them. Professional participants are intermediaries. They provide accounting, information and other services. Self-regulatory organizations protect interests of professional participants and investors and monitor the activities of their own members. The regulatory body for the securities market (at the moment - the Bank of Russia) exercises control and supervision over the activities of all other participants.

Of course, all of these entities interact on the securities market because they have some interest, the implementation of which is possible only as a result of this interaction. At the same time, the very nature of the interest expression is not the same for all the entities. According to the degree of interest in the securities market, development entities are divided into two groups:

- Firstly, entities that have a direct interest in the functioning and development of the regional securities market: regional issuers, investors and professional participants.

- Secondly, entities that have an indirect interest in the functioning and development of the regional securities market: territorial regulators, self-regulatory organizations, regional authorities.

It should be noted that there is one more entity that has an indirect interest in the functioning and development of the securities market at the regional level. The authors speak about the regional authorities. They are not necessarily members of relations on the securities market (for example, the issuer or the investor); but at the same time, they are interested in the overall development of the securities market for ensuring the growth of business and investment activity in the region.

The securities market is always in the process of continuous development (both at the national level, in general, and at the regional level). Currently, in the scientific literature and in practice, there is no single approach to grouping and content of the development factors of the regional securities market. Depending on the affected area, factors are divided into national (affecting the development of the securities market throughout the country) and regional (affecting the development of the securities market within a particular region) ([11], [12]). It was proposed to allocate general and specific factors of development within the regional framework. General factors include economic factors, i.e. factors that are determined by the functioning and development of the regional economy. Specific factors are determined by the features of activity of the regional securities market entities. These activity features can enhance or, conversely, reduce the degree of influence of economic factors on the development of the regional securities market.

The national factors of the regional securities market include: the securities law and the level of development of the securities market, transition to the mega-regulation of the financial markets, the degree of transparency of the securities market and its openness for investors, traditional values of the population, conditions on the global and national financial market, as well as globalization and integration of the financial markets. The effect of the first three factors is caused by the presence (and change) of the rules and regulations of the activity implementation on the securities market. The effect of the last two factors is determined by the influence of the overall economic and financial situation in the country and the world on the securities market.

Regional development factors of the regional securities market are divided into general (economic) and specific ones. General regional development factors include the level of economic development of the region, the regional investment climate, the branch structure of the economy in the region and the processes of reorganization. The effect of these factors is caused by the dependence of the development level of the regional securities market on the development level of the regional economy.

The effect of the specific factors of the regional securities market development, on the one hand, is determined by the activities of regional and quasi-regional participants of the securities market. On the other hand, it reveals the features of the activities of regional and quasi-regional market participants, taking into account their interest in the development of the regional securities market.

Thus, the specific factors are determined by:

1. The features of activity of the regional participants that have a direct interest in the development of the regional securities market. These factors include the choice of the form of raising finance by the regional issuers, investment activity of the population and regional institutional investors, offering services by the regional professional participants of the securities market and others.

2. The features of activity of the regional participants that have indirect interests in the development of the regional securities market. Such factors include taking into account the 
securities market development in the strategy of socioeconomic development of the region and the regional authorities' activities, regional offices of regulatory bodies and branches of self-regulatory organizations.

3. The features of activity of the quasi-regional participants, namely: the expansion of quasi-regional professional participants of the securities market to the regional market, the demand from quasi-regional investors for the securities of the regional issuers and the service of regional professional participants of the securities market, the offer of securities of quasi-regional issuers on the regional market.

Y.M. Mirkin educes the fundamental factors affecting the securities market only at the national level. However, the scientist reveals the content of influence, exerted on the securities market. In his point of view, "the fundamental nature of factors manifests itself in the fact that they significantly affect the economic interests of entities operating on the securities market, changing their economic behavior in the scale which leads to profound changes in the securities market as a system [13]. As part of the research problem, it is necessary to adapt a scheme of impact of factors on the regional securities market, proposed by Y.M. Mirkin.

Hence, for the effective functioning of the securities market, it is necessary to study the features of interaction of the securities market participants and highlight the most important characteristics of this interaction for the purpose of further deliberate influence on the securities market participants.

\section{RESULTS}

In the course of this research, the authors identified different forms of relations between issuers, investors and professional securities market participants, depending on the specific goals they follow in the process of their interaction. The authors propose considering these forms of relations as submodels of the regional securities market:

1. submodel of the inactive market;

2. submodel of the professional mediation;

3. submodel of entering the national securities market;

4. submodel of excess savings;

5. submodel of attracting resources.

It should be noted that these submodels are identified by the criterion of the nature of the relations among the securities market participants. In contrast to the similar studies of the national securities markets [14], this classification of submodels is relevant for the regional level.

A submodel of the inactive market is formed by using securities primarily as property titles. For example, several investors (private or corporate) intend to create a company and choose a joint stock company as a legal form of entity. This results in the accumulation of financial resources from a small number of investors. Accordingly, a redistributive function of the market has a limited expression. The attraction of professional participants of securities market is not required.
The main regional function of the securities market is a function of consolidation of property and non-property rights.

A submodel of the inactive market includes direct operations by the transition of the property rights (sale, donation, etc.) without the mediation of a broker or dealer. Among the professional participants of the securities market only registrars (and, in some cases, depositaries) are involved. Privatization processes can also be attributed to the submodel of the inactive market, as in the case of transformation of the state property into private one, the main entities are the issuers (privatized companies) and investors (the new owners of property rights). And economic relations among them occur with regard to the consolidation of property and non-property rights (both to the securities and the rights to these securities in relation to the corporate issuer).

Another option of this submodel is a re-issue of securities as a result of their conversion. The reasons for the securities' conversion may be reorganization processes, consolidation or a stock split. For example, a limited liability company (LLC) is converted into a joint stock company, and the shares of LLC participants are converted into stocks. In this case, a company does not receive the additional capital, and the issue of stocks only consolidates the property rights.

Thus, the main features of this model are limited implementation (or its absence) of a redistributive function of the securities market, direct funding of companies by a limited range of owners and predominant use of securities as a form of consolidation of property rights to the company.

For the formation of the submodel of the professional mediation, the following conditions should be taken into account: investors become more interested in the securities of the regional issuers at a relatively low level of the securities market development. Purchase-sale transactions of securities take place with the active participation of brokers and dealers. Historically, the operation of this submodel of the regional securities market in Russia was used in the second half of the 1990s when there was a redistribution of the securities of privatized enterprises. The main function of the regional securities market for the submodel of the professional mediation is a function of trade (stock) mediation.

Currently, this submodel is relatively weak. According to the expert estimates done by the National Association of the stock market participants, the scope of activities of the most financial companies (including regional ones) is limited by the organized securities market; issuers are not rendered any qualified help.

So, in contrast to the submodel of the inactive market, the main feature of the submodel of the professional mediation is a full implementation of the redistributive function of the securities market when a professional participant mediates and regulates the supply and demand of securities and the corresponding supply and demand for financial resources.

The securities of regional issuers are traded on the national organized securities market within a submodel of entering the 
national securities market. At the same time, additional financial resources can be mobilized only in subsequent placements of securities directly on exchange platforms. But the very fact of the securities' circulation on the organized market has a positive effect on the business reputation of the company and stimulates the relations of the issuing company with financial institutions (professional participants of the securities market and banks), increasing the capacity to mobilize financial resources afterwards.

Regional issuers, the securities of which are traded on the national organized securities market, increase the number of relations into which they can enter significantly. In fact, the securities of such issuers do not have regional specifics and form the national securities market. The circulation of securities on the organized market engages a lot of investors (both regional and external) and professional securities market participants from different regions in mutual relations. A limitation of this submodel is its main focus on the circulation of already issued securities, i.e. on the secondary market.

This submodel implies attraction (mobilization) of financial resources in case of primary placement of securities; its operation allows the issuer to attract financial resources in terms of more stable demand for securities on the part of the investors.

Thus, the main characteristic of the submodel of entering the national securities market is trading the securities on the organized secondary market.

A submodel of the excess savings implies that private and corporate investors have sufficient monetary funds which are kept in a relatively liquid form. The most suitable instruments in this case are the currency, bank deposits and deposits (including unallocated metal accounts), as well as securities traded on the organized market. When one returns funds from investment to these financial assets, a partial loss of their value is possible, but in general, the investor has the opportunity to return money faster and easier than one does while selling a real estate or share in a limited liability company or illiquid securities of the regional issuers.

It contributes to the development of the financial services market. Financial institutions compete with each other in respect of one service (for example, competition on the market of brokerage services) and with regard to mediation of financial resources as a whole (the competition, in which investors are offered various options of investment, depending on the specifics of the financial institution activity: bank deposits and deposits, unallocated metal accounts, general funds of bank management, brokerage services, dealer services, trust management of securities, agency services for the purchase-sale of investment units). Thus, the financial market in the region begins the struggle for free funds of population and companies; in doing so a specific form of attraction and mediation of these funds may be limited to the only authorized activities for financial institutions. A function of the investment capital concentration becomes a key regional function of the securities market.
This submodel is the most developed in the regions, economies of which produce a great added value. In the regional business centers and regions with developed mining industry, a significant volume of financial resources is accumulated. At the same time, there is a huge potential of the stock mediation. The offer of high-quality securities of regional issuers is generally substantially lower than regional demand for financial assets, so the professional securities market participants contribute to the flow of financial resources to the organized securities market. Accordingly, the relations among regional investors and regional issuers are disrupted. Regional issuers, the securities of which are not traded on the organized securities market, are missing in the scheme of interaction in the excess savings' submodel.

Thus, the main features of the submodel of excess savings are meeting the investors' needs in liquid financial assets, as well as meeting the needs of financial institutions in mediating the funds' flow (and, consequently, the development of commercial activities). At the same time, financial resources are concentrated on the organized securities market, providing the development of not an investment, but a speculative component of the securities market.

The implementation of the submodel of attracting resources is explained by the nature of the economic development of the region and the country as a whole, as well as by a favorable investment climate. Its functioning can have a significant impact on the regional issuers' financing. Thus, innovation-oriented enterprises have a great need for longterm financial resources. These resources are attracted from investment companies which provide venture financing and from the state corporations. The scope of operating activities of the issuers forms investment attractiveness of such securities: the economic entity which issues securities provides high-tech activities. Funds can also be attracted from the public, but very often public, offering securities of small new companies, do not provoke much interest. Therefore, there is a combination of financing by the individual (the author of the innovative idea) and additional financing by legal entities, engaged in venture financing. In addition, in some regions, investment funds of a special regional venture, which invests in small enterprises in the scientific and technical sphere, have been established.

So, all of the proposed submodels are shown in the functioning of the regional securities market. Each submodel represents a set of specific relations between the participants of the regional securities market. The ratio of these submodels in the general model of the functional relations of the regional securities market actually determines the nature of the securities market development in the region and its impact on the regional economy.

It is advisable to build a relational model of the regional securities market based on the proposed submodels of interaction between the participants of the regional securities market and the current system of the securities market regulation. 
In the course of the conducted research, it was revealed that functioning of the regional securities market is based on six functional interconnections: administrative impact, coordinate activities, interaction with the infrastructure of the national level of the organized securities market, interaction between investors and issuers, interaction between investors and professional securities market participants as well as interaction between professional securities market participants and issuers. The reduction of transaction costs as a result of integration of regional economies has led to a substantial increase in the number of relations into which regional securities market entities enter.

Thus, regional issuers, investors and professional securities market participants can interact with each other as well as with third-party issuers, investors and professional participants. In addition, there is an opportunity to participate in securities trading on the organized market. The state regulators and selfregulatory organizations of professional market participants regulate and coordinate these relations.

The regional analysis of the submodels' effect shows that the activity of the relations within the professional mediation and attracting resources depend on the economic development of the entity of the Russian Federation.

Evaluation of a substantial volume of financial resources mediated within the interaction submodels on the regional securities market, in relation to the scale of the regional economies, is presented in Table 1. As a basis for comparison, the rate of investment in the fixed capital was chosen as it reflects the volume of the investment of financial resources in the regional economy.

Table I. The ratio of the volume of financial resources within submodels to investment in the fixed capital in the regions of Western Siberia, \%

\begin{tabular}{|l|c|c|c|c|c|}
\hline \multirow{2}{*}{ Region } & \multicolumn{5}{|c|}{ Submodels } \\
\cline { 2 - 6 } & $\begin{array}{c}\text { Inactive } \\
\text { market }\end{array}$ & $\begin{array}{c}\text { Professional } \\
\text { mediation }\end{array}$ & $\begin{array}{c}\text { Entering the } \\
\text { national } \\
\text { securities } \\
\text { market }\end{array}$ & $\begin{array}{c}\text { Excess } \\
\text { savings }\end{array}$ & $\begin{array}{c}\text { Attracting } \\
\text { resources }\end{array}$ \\
\hline $\begin{array}{l}\text { Altai } \\
\text { Republic }\end{array}$ & - & 0.35 & - & 9.34 & 0.51 \\
\hline $\begin{array}{l}\text { Altai } \\
\text { region }\end{array}$ & 4.67 & 0.38 & - & 4.38 & 0.97 \\
\hline $\begin{array}{l}\text { Kemerovo } \\
\text { region }\end{array}$ & 0.53 & 0.30 & 0.01 & 3.86 & 0.62 \\
\hline $\begin{array}{l}\text { Novosibir } \\
\text { sk region }\end{array}$ & 5.34 & 1.03 & 0.01 & 1.75 & 2.25 \\
\hline $\begin{array}{l}\text { Omsk } \\
\text { region }\end{array}$ & 4.98 & 0.78 & - & 6.46 & 1.24 \\
\hline $\begin{array}{l}\text { Tomsk } \\
\text { region }\end{array}$ & 0.15 & 0.34 & - & 2.73 & 0.98 \\
\hline
\end{tabular}

It is advisable to pay attention to the fact that the largest volume of investment funding in the fixed capital at the expense of the securities market (submodel of attracting resources) takes place in Novosibirsk region (2.25\%). The volume of "lost" investment (i.e., flow of financial resources to the alternative markets in the submodel of excess savings) in Novosibirsk region is, on the contrary, the smallest in
Western Siberia. Therefore, the mechanism of the securities market as a factor of the regional economy development operates most effectively in this entity of the Russian Federation.

When calculating the overall development potential of the relations on the regional securities market, one should take into account that not all interaction submodels reflect the processes of direct financing of the regional economy through the securities market.

The conducted research showed that the development of a submodel of entering the national market and a submodel of attracting resources is the most effective for stimulating the regional economy. The submodel of the professional mediation does not affect the flow of investment to the region directly, but it contributes to the active interaction in the above-mentioned "investment" submodels. Financial resources mediated in the submodel of excess savings have no significant influence on the increase of the financial resources in the regional economy - all monetary funds within this submodel flow to other markets. The submodel of the inactive market does not affect the growth of investment, as it includes only re-issue of securities upon the reorganization of the issuers.

The indicator of the actual contribution of the securities market to the formation of regional investment should be calculated as the total volume of financial resources accumulated within the models of attracting resources and entering the national securities market. The volume of financial resources mediated by the submodel of excess savings is, in fact, the reserve of increasing the efficiency of the regional securities market functioning. The potential for the regional securities market is the sum of these indicators (see Table 2).

Table II. The potential of the regional securities markets for ensuring the flow of investment in the regions of Western Siberia

\begin{tabular}{|c|c|c|c|c|}
\hline Region & $\begin{array}{l}\text { The actual } \\
\text { contribution } \\
\text { of the } \\
\text { securities } \\
\text { market to } \\
\text { the } \\
\text { formation of } \\
\text { investment, } \\
\text { in \% of the } \\
\text { total volume } \\
\text { of } \\
\text { investment } \\
\text { in the fixed } \\
\text { capital }\end{array}$ & $\begin{array}{l}\text { The reserve } \\
\text { of increasing } \\
\text { the } \\
\text { efficiency of } \\
\text { the securities } \\
\text { market } \\
\text { functioning } \\
\text { for } \\
\text { attracting } \\
\text { investment } \\
\text { to the } \\
\text { region, in \% } \\
\text { of the total } \\
\text { volume of } \\
\text { investment } \\
\text { in the fixed } \\
\text { capital }\end{array}$ & $\begin{array}{l}\text { Potential } \\
\text { contribution } \\
\text { of the } \\
\text { securities } \\
\text { market to } \\
\text { the } \\
\text { formation of } \\
\text { investment } \\
\text { in the fixed } \\
\text { capital, in \% } \\
\text { of the total } \\
\text { volume of } \\
\text { investment } \\
\text { in the fixed } \\
\text { capital }\end{array}$ & $\begin{array}{l}\text { The } \\
\text { potential } \\
\text { growth rate } \\
\text { of the } \\
\text { securities } \\
\text { market } \\
\text { contribution } \\
\text { to the } \\
\text { formation of } \\
\text { investment } \\
\text { in the fixed } \\
\text { capital } \\
\text { (compared } \\
\text { with the } \\
\text { actual level), } \\
\text { times }\end{array}$ \\
\hline $\begin{array}{l}\text { Altai } \\
\text { Republ } \\
\text { ic } \\
\end{array}$ & 0.51 & 9.34 & 9.85 & 19.4 \\
\hline $\begin{array}{l}\text { Altai } \\
\text { region }\end{array}$ & 0.97 & 4.38 & 5.36 & 5.5 \\
\hline $\begin{array}{l}\text { Kemer } \\
\text { ovo } \\
\text { region }\end{array}$ & 0.63 & 3.86 & 4.49 & 7.1 \\
\hline
\end{tabular}




\begin{tabular}{|l|c|c|c|c|}
\hline $\begin{array}{l}\text { Novosi } \\
\text { birsk } \\
\text { region }\end{array}$ & 2.25 & 1.75 & 4.01 & 1.8 \\
\hline $\begin{array}{l}\text { Omsk } \\
\text { region }\end{array}$ & 1.24 & 6.46 & 7.70 & 6.2 \\
\hline $\begin{array}{l}\text { Tomsk } \\
\text { region }\end{array}$ & 0.98 & 2.73 & 3.71 & 3.8 \\
\hline
\end{tabular}

Thus, the proposed submodels of interaction between the participants of the regional securities market accumulate a significant volume of financial resources which can be spent on the development of the regional economy. Accordingly, the regions of Western Siberia are able to increase the volume of investments through structural transformation of the regional securities markets. Within the overall relational model of interaction, the reserve of the investment increase is equal to $1.75 \%-9.34 \%$ of the current level of investment in the fixed capital depending on the region. To implement this reserve, it is necessary to strengthen the relations within the submodels of attracting resources and entering the national securities market through the financial resources accumulated by the submodel of excess savings. The development of the regional securities market in this area requires consistent actions of the regional authorities. It leads to the need for a mechanism of the regional securities market development. It is advisable to implement the formation of the effective mechanism of the regional securities market development through the regulation of these relations as well as the reduction of transaction costs on high-priority functional relations.

\section{DISCUSSION AND CONCLUSION}

The targeted development of the regional securities market involves the formation of the mechanism aimed at functioning and development of the regional securities market. The essence of this mechanism is to strengthen important (to stakeholders) relations between the participants of the regional securities market.

The mechanism of the regional securities market development includes the following elements:

1. The purpose of the securities market development in the region.

2. Entities interested in the development of the regional securities market.

3. Requirements for the model of interaction among the participants of the regional securities market.

4. The priority model of interaction among the regional securities market participants (in accordance with the aim of the regional securities market development).

5. Instruments of influence on the securities market participants and the regional market as a whole.

6. The system of qualitative and quantitative indicators to evaluate the achievement of the purpose of the development.

Currently, the most relevant is the development of the regional securities market as a source (of the redistributive mechanism) of the regional economy development.

With the development of the securities market as a source of the regional economy development, the region's economy as a whole seems to be a beneficiary. The realization of this goal is in the interests of all entities involved in the economic relations in the region. Accordingly, while implementation of activities, aimed at the development of the securities market as a source of regional economy development specific actions, is focused on providing sectors (which are priority for the economy of the region) or specific companies (which can have significant positive impact on the economic growth in the region) with financial resources. Thus, the development of the securities market as a source of the regional economy development is based mainly on the submodel of attracting financial resources.

The main submodels of interaction on the regional securities market are the submodel of attracting resources and the submodel of entering the national market. In accordance with the goals of the securities market development, the most important type of functional relations is redistribution of financial resources between issuers and investors. The issuers must be strictly regional. Territorial affiliation of the investors does not matter. Focusing on providing regional issuers with necessary financial resources implies greater involvement of regional investors, third-party investors as well as professional securities market participants for the redistribution of more financial resources.

The main type of functional relations in this case is the interaction of regional issuers and investors (both regional and quasi-regional) about the redistribution of financial resources. It is also advisable to focus on: the relations between regional issuers and regional and quasi-regional professional securities market participants, regarding securities placement; the relations between investors and professional participants in the purchase of the regional issuers' securities; a complex of relations with the national level of the securities market in terms of circulation of securities on the organized market and the issues of regulation and self-regulation of the market.

In the context of achieving the goal, the authors determine the following directions of the securities market development:

- Creation of institutional conditions for the formation of the resource base (for the financing of the financial and economic activities of the regional issuers).

- Assistance to the regional issuers in attracting financial resources on the organized securities market.

Ensuring economic activities of issuers with a resource base involves a range of organizational measures on the part of Executive authorities of the region in terms of creating the institutional conditions for the accumulation of the necessary volume of financial resources, which can then be used to finance priority sectors of the regional economy. The most preferred method of accumulating financial resources in this case is the creation of a specialized mutual investment fund, i.e. a high-risk venture investment fund or a direct investment fund. This fund, accumulating financial resources of the investors, may further direct the money to finance the activities of the regional issuers. Investing through a high-risk 
venture investment fund or a direct investment fund entails a long-term nature of investing in investment objects (in this case - the stocks of joint stock companies and shares of limited liability companies, as well as promissory notes). If a mutual investment fund of the respective categories is financing small and medium-sized enterprises, the investee companies retain benefits in accordance with the law on development of small and medium businesses.

Specific measures of regional authorities aimed at the creation of the institutional conditions for providing regional issuers with financial resources are:

- Identification of priority sectors and areas of the regional economy development.

- Search and negotiations with potential private investors of the fund.

- Selection of a management company for the fund.

- Information and organizational support for the creation of the fund.

- Development of measures of tax and non-tax incentives for regional issuers - investment objects and mutual investment fund investors.

For the efficient organization of the financial resources attraction, it is necessary to clearly determine which branches of the regional economy have primary funding needs. In addition to industries, which are of great importance in ensuring the regional economy functioning, it is also recommended to take into account the innovative nature of the relevant investment fund. As part of the regional economy development, it is advisable to establish two funds: a fund of direct investments (for additional financing of the region's largest enterprises if such enterprises are experiencing a shortage of their own financial resources) or a high-risk venture investment fund (for the issuing companies of innovative orientation).

Tax incentives for the regional fund investors are only possible if the investor carries out tax payments to the budget of the region. In this case, the most appropriate recommendation is to reduce the profit tax rate of organizations on transactions with shares of regional investment funds. In this regard, it is proposed to enshrine the right of the regions to reduce the profit tax rate at the federal level not only for certain categories of taxpayers, but also for individual transactions (in this case - on transactions with shares of the regional investment funds). Accordingly, this right should be enshrined in Article 284 of the Tax Code of the Russian Federation.

Therefore, measures for the development of the securities market as a source of the regional economy development are focused on the creation of the institutional conditions on the formation of the resource base for the regional issuers funding. The creation of these conditions depends primarily on the actions of the regional authorities.

The authors propose the following course of action regarding the organization of the mechanism for the development of the securities market in the region:
1. Taking into account (by the regional bodies of legislative and executive power) the goals of the securities market development in the formulation and approval of the regional economic and financial policy (including the indicators of the securities market development in the list of indicators on the basis of which the achievement of socioeconomic development is assessed).

2. Determination of the need for the development of the securities market as a source of the regional economy development, the creation of the relevant executive body (the department) and the approval of the regulatory framework governing the activities of the regional executive authority in this area.

3. Implementation of the specific measures for the regional securities market development (work on creation of an investment fund, support of the issuers, placing their securities on the organized securities market).

Thus, the comprehensive development of the securities market in the region is in the interest of the securities market participants, the regional authorities and the regional economy as a whole.

According to Keynesian theory, the inflow of investment in the economy stimulates the growth of gross domestic product (at the regional level - the gross regional product), which subsequently also contributes to a further increase in the investment resources. The use of the method of econometric calculations allowed determining that the value of the investment multiplier in the Russian Federation is 1,54 and the value of the investment accelerator is 0,54 [15]. The forecast of GRP and investment growth by the use of the reserve of increasing the efficiency of the regional securities market functioning is given in Table 3.

The most significant growth in GRP and investment in fixed capital in absolute terms is forecasted in Kemerovo and Omsk regions.

Table III. Prognostic indicators of primary influence of increasing the efficiency of the securities market functioning in the regions of Western

\begin{tabular}{|c|c|c|c|c|}
\hline \multirow[t]{2}{*}{ Region } & \multicolumn{2}{|c|}{$\begin{array}{l}\text { GRP growth due to the } \\
\text { impact of investments } \\
\text { (multiplier effect) * }\end{array}$} & \multicolumn{2}{|c|}{$\begin{array}{l}\text { Additional growth of } \\
\text { investment in fixed capital as } \\
\text { a result of GRP growth } \\
\text { (accelerator effect) * }\end{array}$} \\
\hline & $\begin{array}{ll}\text { in } & \text { mln. } \\
\text { Rub. } & \end{array}$ & in $\%$ & in $m \ln . R u b$. & in $\%$ \\
\hline $\begin{array}{l}\text { Altai } \\
\text { Republic }\end{array}$ & 1675.8 & 7.75 & 905.0 & 7.67 \\
\hline $\begin{array}{l}\text { Altai } \\
\text { region }\end{array}$ & 4720.9 & 1.58 & 2549.3 & 3.60 \\
\hline $\begin{array}{l}\text { Kemerovo } \\
\text { region }\end{array}$ & 13195.7 & 2.12 & 7125.7 & 3.17 \\
\hline $\begin{array}{l}\text { Novosibirs } \\
\mathrm{k} \text { region }\end{array}$ & 3785.4 & 0.79 & 2044.1 & 1.44 \\
\hline $\begin{array}{l}\text { Omsk } \\
\text { region }\end{array}$ & 8183.9 & 2.20 & 4419.3 & 5.30 \\
\hline $\begin{array}{l}\text { Tomsk } \\
\text { region }\end{array}$ & 4230.0 & 1.49 & 2284.2 & 2.24 \\
\hline
\end{tabular}


These high rates are attributable to a large volume of identified reserves of increasing the efficiency of the regional securities markets' functioning. In the Altai Republic (the smallest in the absolute, but the largest in relative terms), a positive result from the securities market development is possible. Novosibirsk region is characterized with a relatively low effect on the gross regional product and investments in fixed capital. It implies a current sufficiently high level of the securities market development in this region (which has already been identified on the basis of the analysis of Table 1) and the economy in general.

The authors' forecast takes into account only the initial effect of the mobilization of the reserve of financial resources (excess savings) for the purposes of the regional economy development through the mechanism of the securities market. The overall effect, in the result of multiple actions of the multiplier and accelerator, will manifest itself in the long run. One should also pay attention to the fact that the values used in calculating the multiplier and accelerator are applicable to the economy as a whole.

At the same time, the securities market is the best mechanism for financing innovative-oriented companies. According to the experts of the Russian Venture Capital Association (RVCA), the average internal rate of return for venture capital investment is 35\% per annum, and in the case of channeling funds, which are the reserve of increasing the efficiency of the securities market functioning, the returns on financing of the regional economy may be more significant. In particular, using the above given internal rate of return, it is proposed to determine the impact of venture financing on the development of the regional economy. The authors propose to use two values of a possible venture fund as variants of calculation: $280 \mathrm{mln}$. rub. (the average volume of regional funds for venture capital investments in Russia) and the total volume of the reserve of increasing the efficiency of the securities market functioning.

In the first variant (the establishment of a fund with the initial asset value of 280 million. rub.), the increase of the contribution of issuers, financed from the regional venture investment fund, in the formation of the gross regional product from $0.03 \%$ to $0.08 \%$ ( 2.6 times) for the period from 2016 to 2020 is expected. In case of the second variant of calculation (the establishment of a venture fund with an initial asset value equal to the total amount of the reserve of increasing the efficiency of the securities market functioning), the contribution of issuers who are the investment objects of the regional venture capital fund in the formation of GRP increased from $0.61 \%$ to $1.61 \%$ (about 2, 6 times). For the purpose of balancing the risks of investing in venture projects, it is appropriate to distribute investment resources between securities of a large number of innovative-oriented issuers.

The 2.6-time increase of the contribution by issuers of securities (that are the investment objects of venture capital funds) in the formation of the gross regional product every five years is a very good indicator in the long term. Consequently, the investment stimulation (including venture capital) to the regional economy through the collective investment institutions could have a significant positive impact on the restructuring of the economy and could lay the foundation for sustainable social and economic development of the region.

So, the problem of the development of the regional securities market as a source of the regional economy development is connected with the fact whether regional issuers, investors and professional securities market participants are interested in the collective interaction or not. The specificity of this interaction is reflected in the fact that it is carried out within the proposed interaction submodels on the regional securities market. The impact on these submodels (stimulation or limitation) determines the nature of the regional securities market development. It should be noted that the stakeholders strive primarily for the development of the securities market as a source of the regional economy development. The developed mechanism of the regional securities market development is able to make a big impact on the redistribution of financial resources in the region through the creation of the regional investment fund or stimulation of the emission of securities by the regional issuers for their subsequent placement on the organized securities market. These instruments of the regional securities market development provide economy with necessary long-term investment resources and, consequently, stimulate the increase of the gross regional product. An important organizational aspect is the inclusion of a mechanism of the regional securities market development in the programme (or strategy) of socio-economic development of the region and identification of key indicators of the securities market development. Sustainable development of the regional securities market has a significant impact on the nature and growth of the regional economy. An integrated approach to the impact on the securities market provides effective interaction of its participants and stimulates the economic development of the region as a whole.

\section{Acknowledgment}

The work was carried out with the financial support of the Russian Foundation for Humanities, project No. 16-12-55008.

\section{References}

[1] A.Ye. Miller, A.A. Miller, "Evaluation the Role of Securities Market in Increasing the Regional Budget Revenues", Ekonomika regiona, 3, pp. 216-227, 2015.

[2] M.F. Drigo, "Problems and prospects of the regional securities markets' development", Russian Economic Internet-Journal, 2008, Access: http://www.e-rej.ru/

[3] A.Ye. Miller, I.G. Gorlovskaya, A.A. Miller, "Development of a Mechanism of Increasing Tax Revenues to Regional Budgets through the Development of the Securities Market", Journal of Internet Banking and Commerce, vol. 21, no. S4, pp. 2-11, July 2016.

[4] S.Z. Moshensky, "Securities market: transformation processes", Moscow: "Economy", 240 p., 2010.

[5] T.B. Berdnikova, "Securities market: past, present, future", INFRA-M, 397 p., 2011. 
[6] J. Rosenbaum, "Investment Banking: Valuation, Leveraged Buyouts, and Mergers and Acquisitions", Wiley Finance, 344 p., 2009.

[7] R.J. Teweles, E.S. Bradley, "The Stock Market”, Willey, 344 p., 1982.

[8] V.V. Rossokhin, "The financial resources of Russia and the reasons for their over-concentration in a limited number of assets on the securities market", Finance and Credit, 9, pp. 33-37, 2008.

[9] V.V. Morozov, "Investment potential and reserves of the regional securities market", Bulletin of USTU, 2, pp. 87-92, 2007.

[10] T.V Ignatova., L.V. Boldyreva, "The role of the securities market in the efficient development of the regional financial system", Finance and Credit, 22, pp. 17-23, 2011.

[11] N.K. Rodionova, "Factors affecting the operation of the securities market in the region", Bulletin of Tambov University, Series: Humanities, 4 (44), pp. 297-304, 2006.
[12] E.V. Pylypenko, D.A. Serednikov, "The system of internal and external sourses of the securities market development in the region", Siberian finance school, 4, pp. 81-86, 2008.

[13] Y.M. Mirkin, "Securities market of Russia: the impact of fundamental factors, forecast and policy development", M .: Alpina Publisher, 624 p., 2002.

[14] B.M. Cheskidov, "The securities markets models", SPb.: Peter, 416 p., 2006.

[15] O.I. Rashidov, I.A. Rashidova, M.V. Shatohin, "The analysis of the relations of investment and the GRP on areas of the central black earth region", Economics, 62, pp. 169-174, 2012. 